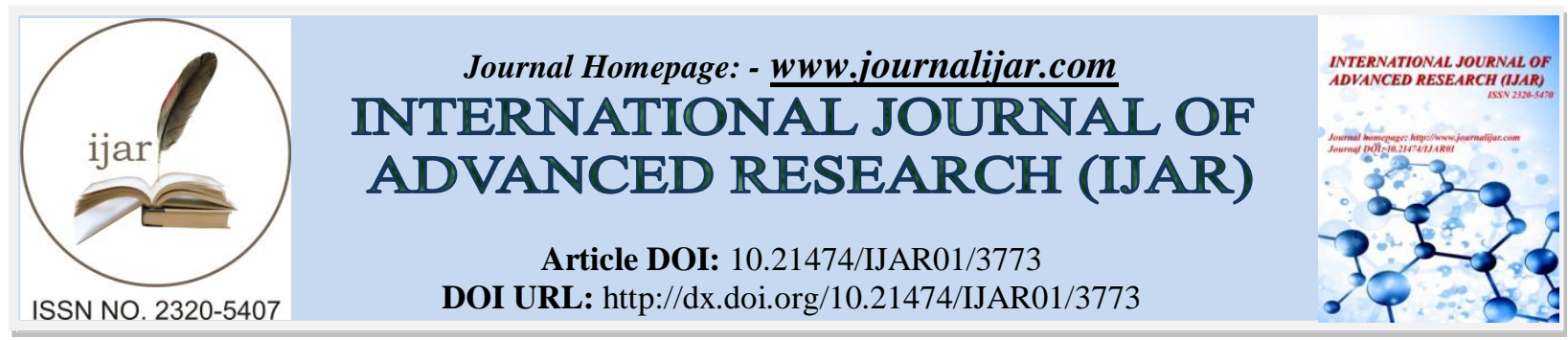

RESEARCH ARTICLE

\title{
EFFECT OF SEED SIZE ON SEED GERMINATION OF AEGLE MARMELOS, L. CORR. , TAMILNADU INDIA.
}

\section{Dr. R. Karthiyayini.}

Assistant Professor, Department of Botany, Avinashilingam Institute for Home Science and Higher Education for Women, Coimbatore-641043, Tamilnadu, India.

\section{Manuscript Info}

Manuscript History

Received: 17 January 2017

Final Accepted: 09 February 2017

Published: March 2017

Key words:-

A. marmelos, Seed germination,

Seedling growth

\begin{abstract}
The present study was undertaken to examine the effect of physical characters seeds on physiological characters like seed germination and seedling growth of A. marmelos L. Corr. Seeds were size graded in to large, medium and small based on seed size (length and breadth) and weight. The result revealed that the size-graded seeds influence the seed germination and seedling growth. The large seeds gave maximum germination followed by medium and small size seeds.
\end{abstract}

Copy Right, IJAR, 2017,. All rights reserved.

\section{Introduction:-}

Aegle marmelos (L.) Corr., is an endangered medicinal tree generally known as Bael belonging to the family Rutaceae. It is a medium sized deciduous and aromatic tree about $12-15 \mathrm{~m}$ height, leaves trifoliate, aromatic, alternate. Leaflets ovate or ovate- lanceolate; greenish white flowers, Large, globose fruits, woody berry (Mazumder et al 2006). It is a popular medicinal plant in Ayurveda and siddha medicines to treat a variety of ailments (Venudevan 2013). Bael fruits are popular due to its medicinal and nutritional properties. Fruits juice is used to cure of diarrhea and dysentery, jaundice, ulcer and eczema (Nadkani 1954). The roots are useful for treating diarrhea and dyspepsia (Pallab Maity 2009). The tree is normally propagated through seeds and seeds required specific quality for better performance with uniformity on seedling production in nursery. However, seeds are exhibit wide varieties such as seed morphological characters as per the influence of development and maturation (Abdul- Baki and Baker, 1973) therefore the present study was conducted to evaivate the effect of seed size and weight on germination and initial growth in the nursery

\section{Materials and Method:-}

\section{Physical characters:-}

Mature fruits of Aegle marmelos, were collected during November to April in Coimbatore district, Tamilnadu, India. The seeds were extracted by macerating the fruits and washed in running water and then air dried at room temperature $\left(28 \pm 2^{\circ} \mathrm{C}\right)$. The seeds were graded into three size grades i.e., large, medium and small. Seed samples (100 seeds) were drawn from each grade and measured for length and breadth using vernier- scale. The length was measured from the base to the tip of the seed and recorded in $\mathrm{cm}$. The breadth was measured at its broadest portion and expressed in $\mathrm{cm}$. One hundred seeds were counted and its weight was recorded in grams using electronic top pan balance as per ISTA (1985) rules. Number of seeds per kilogram was also calculated.

Corresponding Author:- Dr. R. Karthiyayini.

Address:- Assistant Professor, Department of Botany, Avinashilingam Institute for Home Science and Higher Education for Women, Coimbatore-641043, Tamilnadu, India. 


\section{Physiological Characters:-}

Hundred seeds of three different sizes (based seed size) were sown in 30/11 inch polythene bags with holes at the rate of one seed / bag. These bags were filled with sand + red soil (1:1). The weight of the medium was one kilogram in each bag for all cases. The optimum depth was 1.0 to $1.5 \mathrm{~cm}$ below the surface of the soil. There were four replications consisting of one hundred bags /replication. The bags were watered daily. Germination percentage was calculated using the following formula:

$$
\begin{array}{r}
\text { No. of seed g } \\
\text { Germination \% }-100 \\
\text { Total no of seeds sown }
\end{array}
$$

The growth and biomass productions of seedlings were taken once in fifteen days from the date of germination up to 90 days. Ten seedlings in each replication at random were uprooted by cutting the polythene bags without damaging the roots were washed with water. The root and shoot lengths were measured and expressed in $\mathrm{cm}$. The seedlings were dried in a hot-air oven at $60^{\circ} \mathrm{C}$ for 48 hours. After cooling, them in desiccators weighed in electronic top pan balance and expressed in grams.

\section{Result and Discussion:-} Physical Parameter :

The physical characteristics of seeds viz., seed length, seed breath, 100 seeds weight, percentage of occurrence and No. of seeds / $\mathrm{kg}$ was observed and tabulated [Table-1].

The seeds of $A$. marmelos were oblong in shape and milky white in colour. They were size Graded into large, medium and small representing in the ratio of 2:4:1. Seed length, breadth and 100 seed weight were noticed to be more in larger seeds followed by medium and small. Number of seeds / Kg was lowest in larger seeds $5300( \pm 237.1)$ followed by higher number in medium $6437( \pm 515.3)$ and $8125( \pm 772.9)$ in small. Similar seed morphological studies were made by Athaya (1985) in certain tree species growing in tropical dry deciduous mixed forests of central India. Roy [1985] in Albizia lebbeck, Ponnammal et.al ., [1993] in Hardwickia binnata ,Suresh et .al., [2003] in Bassia longifolia and Kathiravan( 2004) in Jatropha.

\section{Physiological characters:-}

Seed grading is a continuous process in seed cleaning in which the seeds are graded according to their size or weight. The purpose of grading is to improve the physiological quality of the seed lot by eliminating small, empty and underdeveloped seeds

Among freshly collected seeds of A. marmelos germination was noticed 6- 10 days after sowing. The large sized seeds exhibited higher (98\%) percentage of germination compared to that of medium and smaller sized seeds ( Fig: 1.) This may be due to large quantity of stored food materials in the larger seeds, which contributed for best germination. The better germination of larger seeds also noticed in, Aholo sercia by Hillum (1990), Syzigium cumini by Ponnammal et al., (1992) and Hardwikia binnata by Ponnammal et al.,(1993). Dalbergia sissoo by Yadav et al., (1998), Bassia longifolia by Suresh et al., (2003) and Pinus wallichiana by Ghildiyal and Sharma (2005)

In the growth performance of the seedlings (90 day old), root and shoot length was higher in large sized seeds (25.1 $\mathrm{cm}$ and $20.3 \mathrm{~cm})$ followed by medium $(22.1 \mathrm{~cm}$ and $16.5 \mathrm{~cm})$ and small $(18.9 \mathrm{~cm}$ and $15.2 \mathrm{~cm})$ respectively. This result conformed that the bigger seeds giving rise to larger seedlings. Due to bigger embryo, which had more nutrients to support more growth has been reported by Ponnusamy et al., (1991) in Neem. Similar findings were also reported by Chauhan and Raina (1980) in Pinus roxburghii., Ponnammal (1992) in Syzigum cumini Arjunan et al., (1995) in Pongamia pinnata and Dar et al ., (2002) in Albizia lebbck, Acacia catechu and Pinus roxburghii. In all these three sized seeds, the root growth was found to be faster than the shoot growth. After 90 days of seed germination, highest biomass production was noticed in seedlings from large seeds $(0.186 \mathrm{~g} / \mathrm{plant})$ (Table.13). 
Table 1:- Physical characters of A. marmelos seeds.

\begin{tabular}{|l|c|c|c|c|c|c|}
\hline \multicolumn{1}{|c|}{ Seed size } & $\begin{array}{c}\text { 100 Seed } \\
\text { weight } \\
(\mathbf{g})\end{array}$ & $\begin{array}{c}\text { Seed length } \\
(\mathbf{c m})\end{array}$ & $\begin{array}{c}\text { Seed } \\
\text { breadth } \\
(\mathbf{c m})\end{array}$ & $\begin{array}{c}\text { Occurrence } \\
(\boldsymbol{\%})\end{array}$ & No. of seeds / Kg & $\begin{array}{c}\text { Seed Shape } \\
\text { and Colour }\end{array}$ \\
\hline Large & $37.0 \pm 1.85$ & $0.81 \pm 0.09$ & $0.38 \pm 0.05$ & $20-25$ & $5300 \pm 237.1$ & $\begin{array}{c}\text { Oblong } \\
\text { Milky White }\end{array}$ \\
\hline Medium & $30.0 \pm 3.29$ & $0.65 \pm 0.05$ & $0.32 \pm 0.04$ & $55-60$ & $6437 \pm 515.3$ & \\
\hline \multicolumn{2}{|r|}{ Small } & $22.0 \pm 2.94$ & $0.48 \pm 0.06$ & $0.25 \pm 0.07$ & $18-22$ & $8125 \pm 772.9$ \\
\hline
\end{tabular}

$\pm=$ Standard deviation
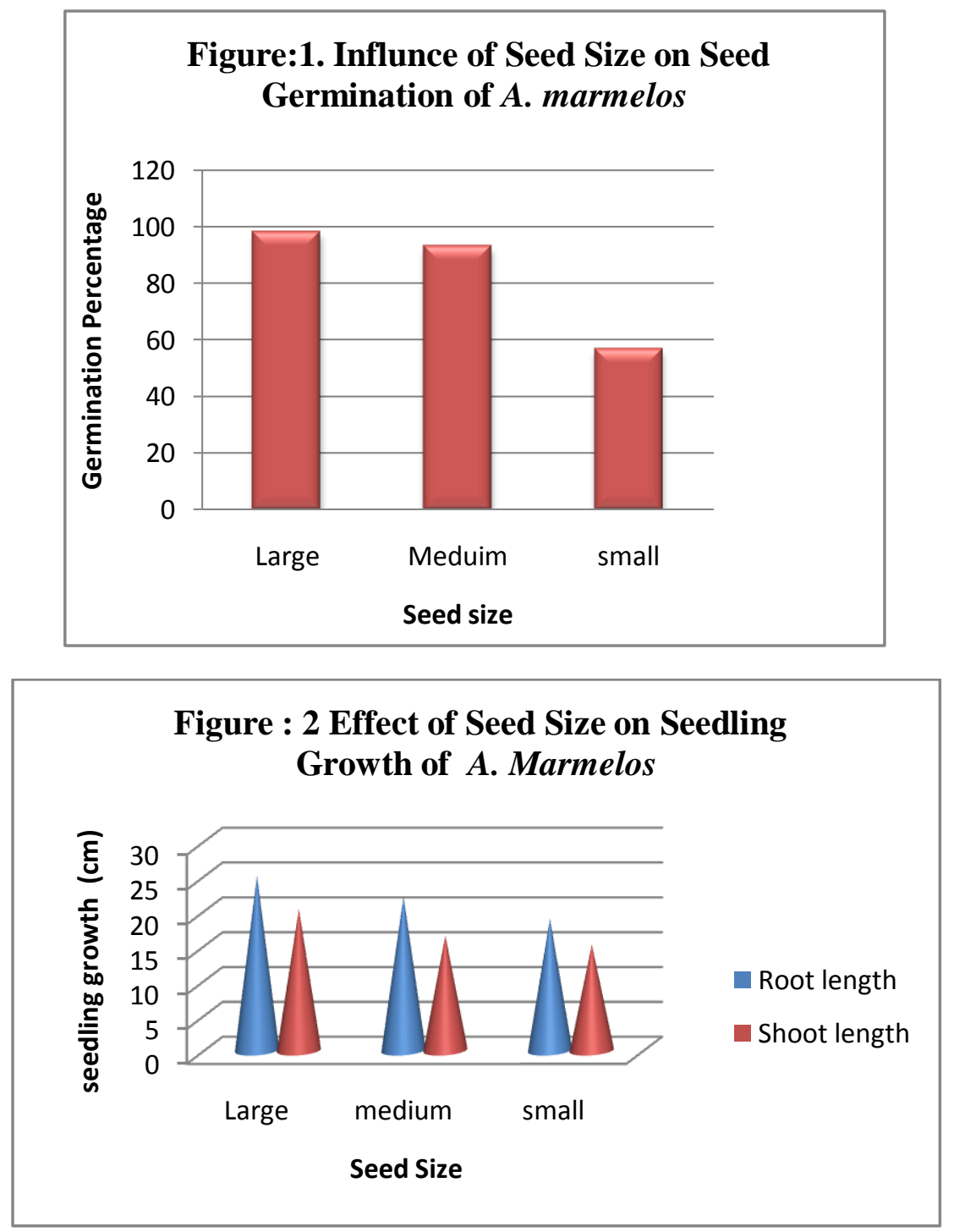

\section{Conclusion:-}

Seed is one of the most important inputs for forest nursery production. Based on the results of the present study, seed germination and seedling growth characters were higher in larger seeds. So this study concluded that the seed size and seed quality are positively related. 


\section{Reference:-}

1. Abdul- Baki A.A and Baker J.E., 1973 Are changes in cellular organelles or membranes related to vigour loss in seed. Seed Sci. and Technol. 1: 89-125.

2. Arjunan, M.C., M. Tamilselvi, and K.K. Lakshmanan.1996. Morphology of pods and seeds in some tree species. Madras Agric. J., 83: 392-394.

3. Athaya, C.D., 1985 Ecological studies of some forest tree seeds. I seed morphology. Indian. J. For., 8 :33-36.

4. Chauhan, P.S. and V. Raina, 1980. Effect of seed weight on germination and growth of chir pine (Pinus roxburghin sargent). Indian For, 106: 89-93.

5. Dar, Farooq Ahamad, Mohit Gera and Nelu Gera. 2002. Effect of seed greading on germination pattern of some multipurpose tree species of Jammu region. Indian For., 128(5): 509-513.

6. Ghildiyal, S.K and C.M. Sharma 2005. Effect of seed size and temperature treatments on germination of various seeds. Indian For., 13(1):57-65.

7. HillumA. K. 1990. Grading seed by weight in white spruce (Picea glauca). Tree Planters Notes, 27:16,17-23.

8. Kathiravan M. ( 2004). Seed production, processing, testing and storage techniques in Jatropha (Jatropha curcus Linn. ). Ph.D Thesis , Tamilnadu Agricultural University, Coimbatore

9. Mazumder R. Bhattacharya S, Mazumder A, Pattnailk AK, Tiwary Pm, Chaudhary S, 2006. Antidiarrhoeal evaluation of Aegle marmelos (Correa) Linn. Root extact. Phytoth. Res. 20:82-84.

10. Nadkarni, A.K. 1954. Indian Materia Medica, popular Book Depot, Bombay pp:113.

11. Pallab Maity,Dhananjay Hansda, Uday Banyopadhya and Dipak Kumar Mishra. 2009 Biological activities of curde extracts and chemical constituents of Bael, Aegle marmelos (L.) corr. Indian J. of Exp. Biol., 47: 849861.

12. Ponnammal, N.R., M.C. Arjunan, T. Gunnamani and K.A. Antony, 1993. Germination and seedling growth of Azadirachta indica A. Juss. J. Tree Sci.,12(2): 65-68

13. Ponnammal, N.R., K.A. Antony, and M.C. Arjunan, 1992. Seed polymorphism, seed germination and seedling biomass in Syzigium cumini (L) skeels. J. Trop. For., 8: 155-159.

14. Ponnusamy et al., (1991) Ponnusamy, A.S., R.S. Vinaya Rai, C. Surendran, and T.V. Karivaratharaju, 1991. Studies on maintaining seed longevity and the effect of fruit grades on neem (Azadirachta indica A. Juss) J. Tropical For., Sci., 3: 285-290.

15. Roy [1985] Roy, M.M., 1985. Seed polymorphism and germination in Albizia lebbeck. Van Vigyan, $23: 23-28$.

16. Suresh, K.K., I. Sekar. and A. Vijayaraghavan, 2003. Effect of seed color and seed size on Seedling quality in Bassia Longifolia Linn. My forest Vol. 39(2): 179-184.

17. Venudevan B. P. Srimathi, N, Natarajan and R.M. Vijayakumar. 2013. Influence of fruit polymorphism on seed and seedling quality characters of Bael( Aegle marmelos )the endangerd medicinal tree. Asian J. of Crop Science: DOI : 10.3923/ajcs pages 1-7 